ҚАЗАҚСТАН РЕСПУБЛИКАСЫ

ҰЛТТЫҚ ҒЫЛЫМ АКАДЕМИЯСЫНЫН

АБАЙ АТЫНДАҒЫ ҚАЗАҚ ҰЛТТЫҚ

ПЕДАГОГИКАЛЫҚ УНИВЕРСИТЕТІНІҢ

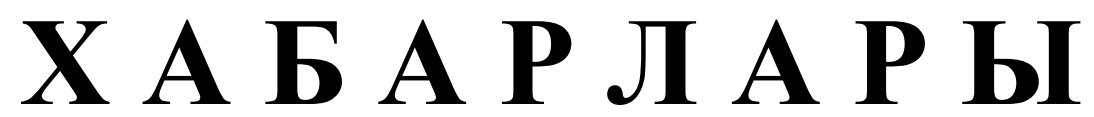

\section{ИЗВЕСТИЯ}

НАЦИОНАЛЬНОЙ АКАДЕМИИ НАУК РЕСПУБЛИКИ КАЗАХСТАН

КАЗАХСКИЙ НАЦИОНАЛЬНЫЙ

ПЕДАГОГИЧЕСКИЙ УНИВЕРСИТЕТ ИМ. АБАЯ

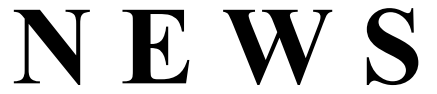

OF THE NATIONAL ACADEMY OF SCIENCES OF THE REPUBLIC OF KAZAKHSTAN

ABAY KAZAKH NATIONAL PEDAGOGICAL UNIVERSITY

ҚОҒАМДЫҚ ЖӘНЕ ГУМАНИТАРЛЫҚ ҒЫЛЫМДАР СЕРИЯСЫ

СЕРИЯ ОБЩЕСТВЕННЫХ И ГУМАНИТАРНЫХ НАУК

$\checkmark$

SERIES OF SOCIAL AND HUMAN SCIENCES

$$
5 \text { (321) }
$$

КЫРКУЙЕК - КАЗАН 2018 ж.

СЕНТЯБРЬ - ОКТЯБРЬ 2018 Г.

SEPTEMBER - OCTOBER 2018

1962 ЖЫЛДЫҢ ҚАНТАР АЙЫНАН ШЫҒА БАСТАҒАН

ИЗДАЕТСЯ С ЯНВАРЯ 1962 ГОДА

PUBLISHED SINCE JANUARY 1962

ЖЫЛЫНА 6 РЕТ ШЫҒАДЫ

ВЫХОДИТ 6 РАЗ В ГОД

PUBLISHED 6 TIMES A YEAR 
Ба с ре дактор

ҚР ҰҒА кұрметті мүшесі

Балықбаев Т.O.

Р е д а ц и я а лқ а сы:

экон. ғ. докторы, проф., ҚР ҰҒА академигі Баймұратов У.Б.; тарих ғ. докторы, проф., ҚР ҰҒА академигі Байпақов К.М.; филос. ғ.докторы, проф., ҚР ҰҒА академигі Есім Г.Е.; фил. ғ. докторы,, проф., ҚР ҰҒА академигі Қирабаев С.С.; эк. ғ. докторы, проф., ҚР ҰҒА академигі Кошанов А.К.; эк.ғ. докторы, проф., ҚР ҰҒА академигі Нәрібаев К.Н. (бас редактордың орынбасары); филос. ғ.докторы, проф., ҚР ҰҒА академигі Нысанбаев А.Н.; заң ғ. докторы, проф., ҚР ҰҒА академигі Сәбікенов С.Н.; заң ғ. докторы, проф., ҚР ҰҒА академигі Сүлейменов М.К.; эк. ғ. докторы, проф., ҚР ҰҒА академигі Сатыбалдин С.С.; тарих ғ. докторы, проф., ҚР ҰҒА академик Әбжанов Х.М.; тарих ғ. докторы, проф., ҚР ҰҒА корр. мүшесі Әбусеитова М.Х.; тарих ғ. докторы, проф., ҚР ҰҒА академик Байтанаев Б.А.; филол. ғ. докторы, проф., ҚР ҰҒА корр. мүшесі Жақып Б.А.; фил. ғ. докторы, проф., академик НАН РК Қалижанов У.К.; филол. ғ. докторы, проф., ҚР ҰҒА академик Қамзабекұлы Д.; тарих ғ. докторы, проф., ҚР ҰҒА академик Қожамжарова Д.П.; тарих ғ. докторы, проф., ҚР ҰҒА академик Койгелдиев М.К.; фил. ғ. докторы, проф., ҚР ҰҒА корр. мүшесі Кұрманбайұлы Ш.; тарих ғ. докторы, проф., ҚР ҰҒА корр. мүшесі Таймағанбетов Ж.К.; социол. ғ. докторы, проф., ҚР ҰҒА корр. мүшесі Шәукенова 3.К.; фил. ғ. докторы, проф., КР ҰҒА корр. мүшесі Дербісәлі А.; саяси. ғ. докторы, проф., Бижанов А.К., тарих ғ. докторы, проф., Кабульдинов 3.Е.; фил. ғ. докторы, проф., ҚР ҰҒА корр мүшесі Қажыбек Е.3.

\section{Р едакция ке н е с i:}

Молдова Республикасының ҰҒА академигі Белостечник Г. (Молдова); Әзірбайжан ҰҒА академигі Велиханлы Н. (Азербайджан); Тәжікстан ҰҒА академигі Назаров Т.Н. (Тәжікстан); Молдова Республикасының ҰҒА академигі Рошка А. (Молдова); Молдова Республикасының ҰҒА академигі Руснак Г. (Молдова); Әзірбайжан ҰҒА корр. мүшесі Мурадов Ш. (Әзірбайжан); Әзірбайжан ҰҒА корр. мүшесі Сафарова 3. (Әзірбайжан); э. ғ. д., проф. Василенко В.Н. (Украина); заң ғ. докт., проф. Устименко В.А. (Украина)

«Қазақстан Республикасы Ұлттық ғылым академиясының Хабарлары. Қоғамдық және гуманитарлық ғылымдар сериясы». ISSN 2224-5294

Меншіктенуші: «Қазақстан Республикасының Ұлттық ғылым академиясы» РҚБ (Алматы қ.)

Қазақстан республикасының Мәдениет пен ақпарат министрлігінің Ақпарат және мұрағат комитетінде 30.04.2010 ж. берілген № 10894-Ж мерзімдік басылым тіркеуіне қойылу туралы куәлік

Мерзімділігі: жылына 6 рет.

Тиражы: 500 дана.

Редакцияның мекенжайы: 050010, Алматы қ., Шевченко көш., 28, 219 бөл., 220, тел.: 272-13-19, 272-13-18, http://nauka-nanrk.kz. social-human.kz

(C) Қазақстан Республикасының Ұлттық ғылым академиясы, 2018

Типографияның мекенжайы: «Аруна» ЖК, Алматы қ., Муратбаева көш., 75. 
Главный редакто $p$

Почетный член НАН РК

T.O. Балыкбаев

Р е дак ци онн а я коллег и я:

докт. экон. Н., проф., академик НАН РК У.Б. Баймуратов; докт. ист. н., проф., академик НАН РК К.М. Байпаков; докт. филос. Н., проф., академик НАН РК Г.Е. Есим; докт. фил. Н., проф., академик НАН РК С.С. Кирабаев; докт. экон. Н., проф., академик НАН РК А.К. Кошанов; докт. экон. Н., проф., академик НАН РК К.Н. Нарибаев (заместитель главного редактора); докт. филос. н., проф., академик НАН РК А.Н. Нысанбаев; докт. юр. Н., проф., академик НАН РК С.Н. Сабикенов; докт. юр. н., проф., академик НАН РК М.К. Сулейменов; докт. экон. Н., проф., академик НАН РК С.С. Сатубалдин; докт. ист. н., проф., академик НАН РК Х.М. Абжанов; докт. ист. н., проф., чл.-корр. НАН РК М.Х. Абусеитова; докт. ист. н., проф., академик НАН РК Б.А. Байтанаев; докт. фил. н., проф., чл.-корр. НАН РК Б.А. Жакып; докт. фиолол. н., проф., академик НАН РК У.К. Калижанов; докт. фил. н., проф., академик НАН РК Д. Камзабекулы; докт. ист. н., проф., академик НАН РК Д.П. Кожамжарова; докт. ист. н., проф., академик НАН РК М.К. Койгельдиев; докт. филол. н., проф., чл.-корр. НАН РК Ш. Курманбайулы; докт. ист. н., проф., чл.корр. НАН РК Ж.К. Таймаганбетов; докт. социол. н., проф., чл.-корр. НАН РК З.К. Шаукенова; д. филол. н., проф., чл.-корр. НАН РК А. Дербисали; доктор политических наук, проф., Бижанов А.К.; доктор ист. наук, проф., Кабульдинов 3.Е.; доктор филол. н., проф., член-корр. НАН РК Қажыбек Е.3.

Р е дак ци онны й с ов е т

академик НАН Республики Молдова Г. Белостечник (Молдова); академик НАН Азербайджанской Республики Н. Велиханлы (Азербайджан); академик НАН Республики Таджикистан Т.Н. Назаров (Таджикистан); академик НАН Республики Молдова А. Рошка (Молдова); академик НАН Республики Молдова Г. Руснак (Молдова); чл.-корр. НАН Азербайджанской Республики Ш. Мурадов (Азербайджан), член-корр. НАН Азербайджанской Республики 3.Сафарова (Азербайджан); д. э. н., проф. В.Н. Василенко (Украина); д.ю.н., проф. В.А. Устименко (Украина)

Известия Национальной академии наук Республики Казахстан. Серия общественных и гуманитарных наук. ISSN 2224-5294

Собственник: РОО «Национальная академия наук Республики Казахстан» (г. Алматы)

Свидетельство о постановке на учет периодического печатного издания в Комитете информации и архивов

Министерства культуры и информации Республики Казахстан № 10894-Ж, выданное 30.04.2010 г.

Периодичность 6 раз в год

Тираж: 500 экземпляров

Адрес редакции: 050010, г. Алматы, ул. Шевченко, 28, ком. 219, 220, тел. 272-13-19, 272-13-18, www:nauka-nanrk.kz / social-human.kz

(C) Национальная академия наук Республики Казахстан, 2018 г.

Адрес типографии: ИП «Аруна», г. Алматы, ул. Муратбаева, 75

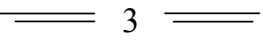


Chief Editor

\section{Honorary member of NAS RK \\ Balykbayev T.O}

Editorial board:

Doctor of economics, prof, academician of NAS RK Baimuratov U.B.; doctor of history, prof, academician of NAS RK Baipakov K.M.; doctor of philosophy, prof, academician of NAS RK Esim G.E.; doctor of philology, prof, academician of NAS RK Kirabayev S.S.; doctor of economics, prof, academician of NAS RK Koshanov A.K.; doctor of economics, prof, academician of NAS RK Naribayev K.N. (deputy editor-in-chief); doctor of philosophy, prof, academician of NAS RK Nyssanbayev A.N.; doctor of law, prof, academician of NAS RK Sabikenov S.N.; doctor of law, prof, academician of NAS RK Suleymenov M.K.; doctor of economy, prof, academician of NAS RK Satybaldin S.S.; doctor of history, prof, academician of NAS RK Abzhanov H.M; doctor of history, prof, corresponding member of NAS RK Abuseitova M.H.; doctor of history, prof, academician of NAS RK Baitanaev B.A.; doctor of philology, prof, corresponding member of NAS RK Zhakyp B.A.; doctor of philology, prof, academician of NAS RK Kalizhanov U.K.; doctor of philology, prof, academician of NAS RK Hamzabekuly D.; doctor of history, prof, academician of NAS RK Kozhamzharova D.P.; doctor of history, prof, academician of NAS RK Koigeldiev M.K.; doctor of philology, prof, corresponding member of NAS RK Kurmanbaiuly Sh.; doctor of history, prof, academician of NAS RK Taimaganbetov J.K.; doctor of sociology, prof, corresponding member of NAS RK Shaukenova Z.K.; doctor of philology, prof, corresponding member of NAS RK Derbisali A.; doctor of political science, prof Bizhanov A.K; doctor of History, prof Kabuldinov Z.E.; doctor of philology, prof, corresponding member of NAS RK Kazhybek E.Z.

\section{Editorial staff:}

Academician NAS Republic of Moldova Belostechnik.G (Moldova); Academician NAS Republic of Azerbaijan Velikhanli N. (Azerbaijan); Academician NAS Republic of Tajikistan Nazarov T.N. (Tajikistan); Academician NAS Republic of Moldova Roshka A. (Moldova) Academician NAS Republic of Moldova Rusnak G. (Moldova); Corresponding member of the NAS Republic of Azerbaijan Muradov Sh. (Azerbaijan); Corresponding member of the NAS Republic of Azerbaijan Safarova Z. (Azerbaijan); Associate professor of Economics Vasilenko V.N. (Ukraine), Associate professor of Law Ustimenko V.A. (Ukraine)

News of the National Academy of Sciences of the Republic of Kazakhstan. Series of Social and Humanities. ISSN 2224-5294

Owner: RPA "National Academy of Sciences of the Republic of Kazakhstan" (Almaty)

The certificate of registration of a periodic printed publication in the Committee of information and archives of the Ministry of culture and information of the Republic of Kazakhstan N 10894-Ж, issued 30.04.2010

Periodicity: 6 times a year

Circulation: 500 copies

Editorial address: 28, Shevchenko str., of. 219, 220, Almaty, 050010, tel. 272-13-19, 272-13-18, www:nauka-nanrk.kz / social-human.kz

(C) National Academy of Sciences of the Republic of Kazakhstan, 2018

Address of printing house: ST "Aruna", 75, Muratbayev str, Almaty 
N E W S

OF THE NATIONAL ACADEMY OF SCIENCES OF THE REPUBLIC OF KAZAKHSTAN

SERIES OF SOCIAL AND HUMAN SCIENCES

ISSN 2224-5294

https://doi.org/10.32014/2018. 2224-5294.28

Volume 5, Number 321 (2018), 166 - 173

UDC $336.71 .02(574)$

\author{
G.T. Sultanova ${ }^{1}$ \\ JSC "Financial Academy", Astana, the Republic of Kazakhstan \\ guzel1010@mail.ru
}

\title{
TRENDS AND PRIORITIES FOR THE DEVELOPMENT OF EXPORT POTENTIAL OF THE AGRARIAN SECTOR
}

\begin{abstract}
The urgency of the development of scientific research is determined by the fact that the agroindustrial complex The agro-industrial complex is the main and most promising branch of the economy of Kazakhstan. Few countries in the world have the potential for agricultural development, comparable to the potential of Kazakhstan. Already today it becomes obvious that, in the future, with the growth of the world's population, countries that are able to export food will become the main ones on the world market. In Kazakhstan, much attention is paid to the development of the agro-industrial complex. The volume of financing of the industry is increasing, new programs are being developed, new instruments of state support are being created. Statistics show positive dynamics: gross output increases, investment in the sector grows, new agricultural objects appear

In this report, the matrix of the agro-industrial complex is presented, which allows to determine the place to promote innovative development of agriculture, mechanization and intellectualization of labor, as well as to ensure transition to resource-saving technologies, as well as to develop the export potential of the agricultural sector.

Key words: tendencies, agro-industrial complex, food products, state support, gross agricultural output, mechanism of agricultural development, intellectualization of labor, resource-saving technologies.

Introduction. In the Message to the People of Kazakhstan of January 10, 2018, "New Development Opportunities in the Conditions of the Fourth Industrial Revolution", the President of the country, N.A. Nazarbayev clearly noted: "Smart technologies" - a chance for a breakthrough in the development of the agro-industrial complex. " This is our traditional industry. The global need for food will grow. The agrarian policy should be aimed at a radical increase in labor productivity and growth in exports of processed agricultural products. Provision and processing of raw materials and reorient the entire agroindustrial complex to this task. At the same time, the head of state stressed the need to revise the role of agrarian universities, and a multiple increase in productivity can be achieved through technologies for predicting the optimal time for sowing and harvesting, "smart irrigation," intelligent mineral fertilization systems, and pest and weed control. It is necessary to increase labor productivity in the agroindustrial complex and export of processed agricultural products at least 2.5 times within 5 years [1].

In the agricultural sector of Kazakhstan, there is a high dependence on natural and climatic conditions, a high proportion of agricultural production in the households, low labor productivity, a weak credit system, the use of simplified technologies for cultivating crops and growing animals, low technical equipment and insufficient introduction of innovative technologies, which prevents the effective conduct of production.

Research methods - the agro-industrial complex of the Republic of Kazakhstan has good prospects for further development: the export positions of the oilseed and meat sectors are increasing, and in terms of grain and flour, Kazakhstan has become one of the largest exporting countries in the world as soon as possible. Kazakhstan's membership in the Eurasian Economic Union (hereinafter referred to as the EAEC) and the World Trade Organization (WTO) creates opportunities and at the same time makes high demands on competitiveness in both the domestic and foreign markets. In this regard, the role of state regulation of the agro-industrial complex is extremely important.
\end{abstract}

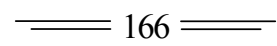


During the period of independence, nine program documents were developed on the basis of which the state policy in the sphere of the agro-industrial complex was implemented: the Aul socio-economic development program for 1991-1995 and for the period up to 2000, the Conceptual Program for the Development of the Agro-industrial Complex for 1993-1995 and up to 2000, the Program for the Development of Agricultural Production for 2000-2002, the State Agro-Food Program for 2003-2005, the State Program for the Development of Rural Areas for 2004-2010, the Concept of Sustainable Development of the Agro-industrial Complex for 2006 2010-2010, the Program of Priority Measures for the Implementation of the Concept of Sustainable Development of the AIC of the Republic of Kazakhstan for 2006-2010, the Agro-Industrial Development Program for 2010-2014 and the Agro-business development program in the Republic of Kazakhstan "Agro-business 2017".

The results of the study - lead to the fact that in agriculture, about $5 \%$ of the country's gross domestic product (hereinafter - GDP) is created. In 2015, the gross output of agriculture amounted to 3.3 trillion. KZT, which in real terms below the level of 2011 by $4.1 \%$.

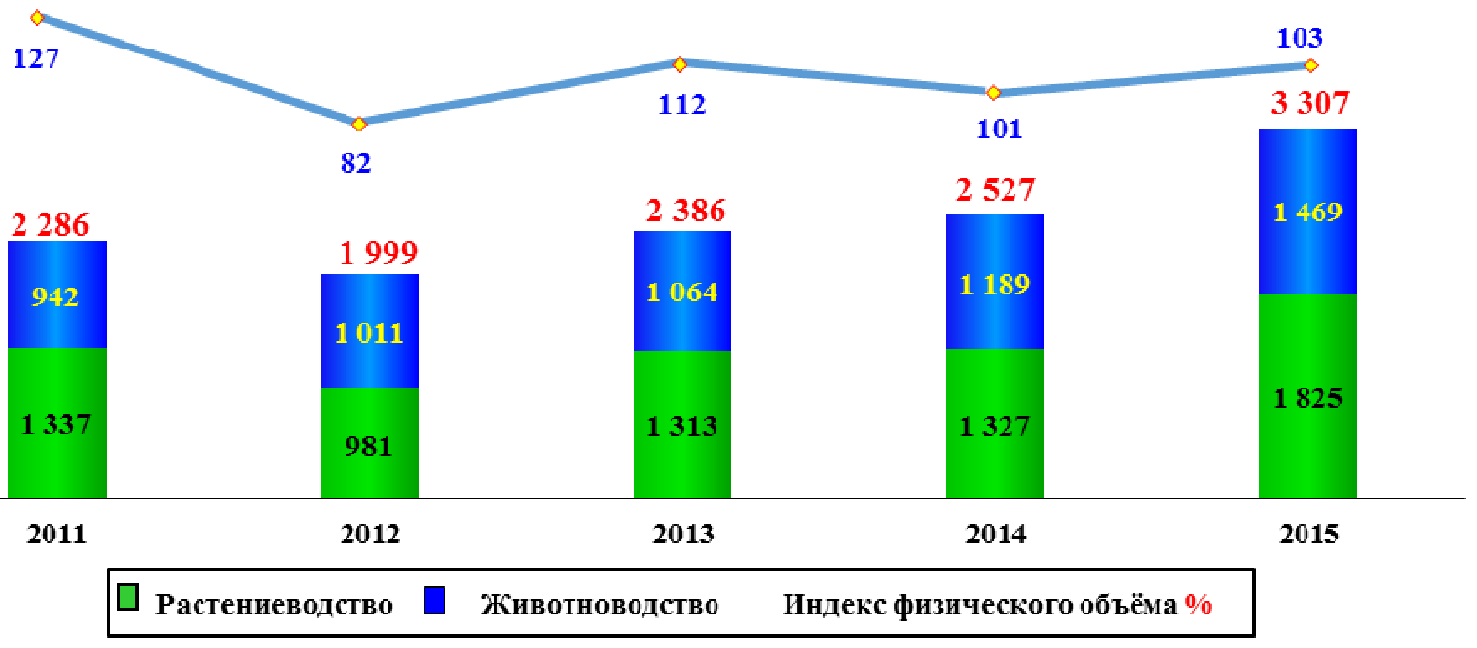

Растениеводство- crop production

Животноводство-animal husbandry

Индекс физического объема- Index of physical volume

Diagram 1. Dynamics of gross productionf agriculture, billion tenge

In the structure of the gross output of the industry there is a high share of production of personal subsidiary plots. About $80 \%$ of agricultural products produced in Kazakhstan are sold as raw materials, without processing, and finished products have weak competitiveness [2].

Table 1- SWOT analysis of the AIC industry

\begin{tabular}{|c|c|}
\hline Strengths & Weaknesses \\
\hline $\begin{array}{l}\text { - Kazakhstan takes the ninth place on the territory in the } \\
\text { world; } \\
\text { - Kazakhstan occupies the second place in the world in } \\
\text { terms of arable land per capita; } \\
\text { - Kazakhstan is one of the largest exporters of grain and } \\
\text { flour; } \\
\text { - a multitude of rural population ( } 43 \% \text { of the total } \\
\text { population), a high proportion of employed ( } 18 \% \text { of the } \\
\text { employed population); } \\
\text {-a large potential demand for food products markets of the } \\
\text { CIS countries and Central Asia; } \\
\text {-constant growth of the gross product of the agro-industrial } \\
\text { complex; } \\
\text {-high production and export potential of organic products }\end{array}$ & $\begin{array}{l}\text {-low share in the country's GDP (4.8\%); } \\
\text {-development of trade, including export; } \\
\text {-low level of implementation of research and development; } \\
\text { - Insufficient level of veterinary and food safety; } \\
\text { - High capital intensity; } \\
\text {-long payback period; } \\
\text {-dependence on natural and climatic conditions; } \\
\text {-low labor productivity; } \\
\text {-low level profitability of SHPP }\end{array}$ \\
\hline
\end{tabular}




\begin{tabular}{|l|l|}
\hline \hline \multicolumn{1}{|c|}{ Opportunities } & \multicolumn{1}{|c|}{ Threats } \\
\hline - the possibility of increasing volumes for all types of & $\begin{array}{l}\text { - unfavorable changes in natural and climatic conditions, } \\
\text { agricultural products due to the growing number and } \\
\text { instability of weather conditions; } \\
\text { changing structure of the population's nutrition; }\end{array}$ \\
-formation of effective state support of SCPP and & $\begin{array}{l}\text { - spread of diseases of animals and plants and pollution of the } \\
\text { natural environment; } \\
\text { agricultural cooperatives; }\end{array}$ \\
$\begin{array}{l}\text { - Growth of competition in international markets for certain } \\
\text { promising sectors }\end{array}$ & $\begin{array}{l}\text { types of products in connection with accession to the WTO; } \\
\text { risk of inefficient state regulation of the industry }\end{array}$ \\
\hline
\end{tabular}

The average annual growth rates of food production in general do not keep pace with the growth rates of consumption and income of the population, as a result of which the free niche in the market is filled by imports and its share in domestic consumption remains very significant.

The gross output of food production in 2017 amounted to 1.1 trillion. KZT, which in real terms is higher than the level of 2013 by $12.5 \%$.

The main share in the structure of food production is occupied by the grain processing industry $(22.3 \%)$, dairy $(16.7 \%)$, bakery $(15 \%)$, meat processing $(13.6 \%)$, fat and oil $(7.9 \%)$, fruit and vegetable $(7$ , 6\%) and other industries (16.9\%).

Kazakhstan, which has a great potential for agricultural production, still imports a lot of food (40\%), and the industry itself is not developing fast enough. The main problem of the agro-industrial complex is the low level of state support [3].

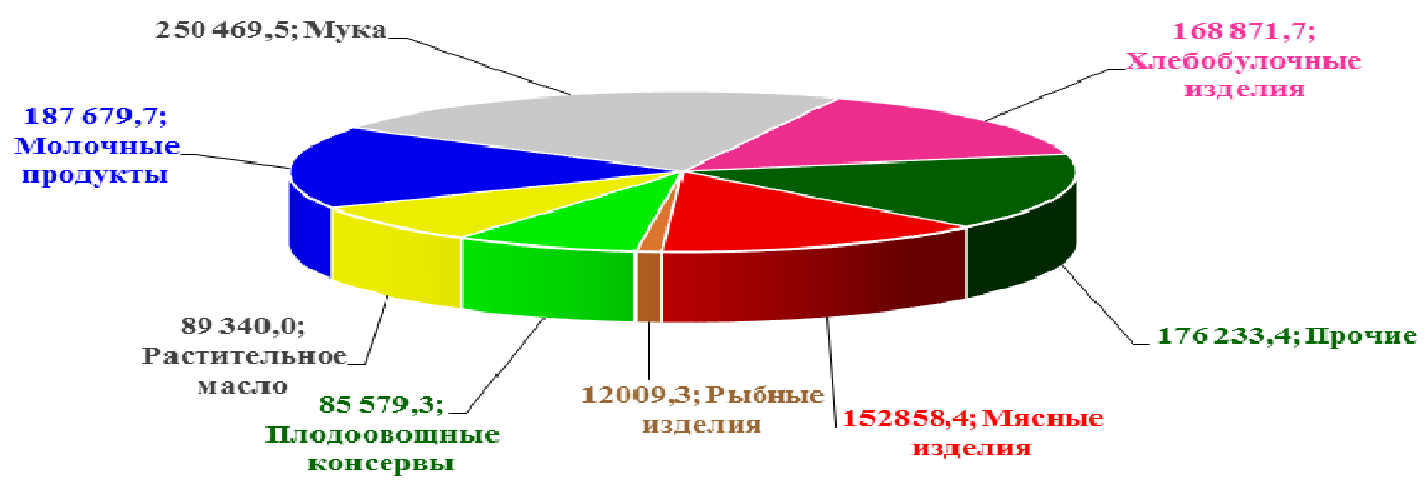

Diagram 2 - Production of agricultural products in monetary terms in 2017, m. Tenge

The volume of foreign trade turnover on products of processing of agricultural raw materials and the food-processing industry of the country in 2017 amounted to 3.2 billion US dollars, which is $17.7 \%$ less than in 2013 (3.8 billion US dollars).

The volume of exports by products of processing of agricultural raw materials and food industry decreased by $6.5 \%$ (from 1.0 to 0.9 billion US dollars).

The volume of imports in 2017 compared with 2013 decreased by $21.6 \%$ and amounted to 2.3 billion US dollars.

A high share of imports is maintained by the most high-tech industries. On average, for five years, the largest share of imports for products of processing livestock products is cheese and curd (51\%), sausages $(46 \%)$, meat and canned meat $(40 \%)$ and butter $(36.4 \%)$. By products of processing of plant products, the largest share of imports is recorded for sugar (42\%), and taking into account the import of cane sugar, imports reach $97 \%$. At the same time, the production capacity of sugar factories was loaded by $37.1 \%$. Import of canned fruits and vegetables in 2015 amounted to 98.7 thousand tons, or $84 \%$ of domestic consumption, while the fruit and vegetable processing enterprises were busy at $27 \%$. The share of imports in domestic consumption of oil and fat products reaches 30-40\%. At the same time, capacities of oil and fat companies are loaded by $45-50 \%$. The problem of lack of quality raw materials for loading production capacities is acute for the entire processing industry as a whole. The production of cereals and flour completely ensures internal consumption [4].

$$
=168=
$$




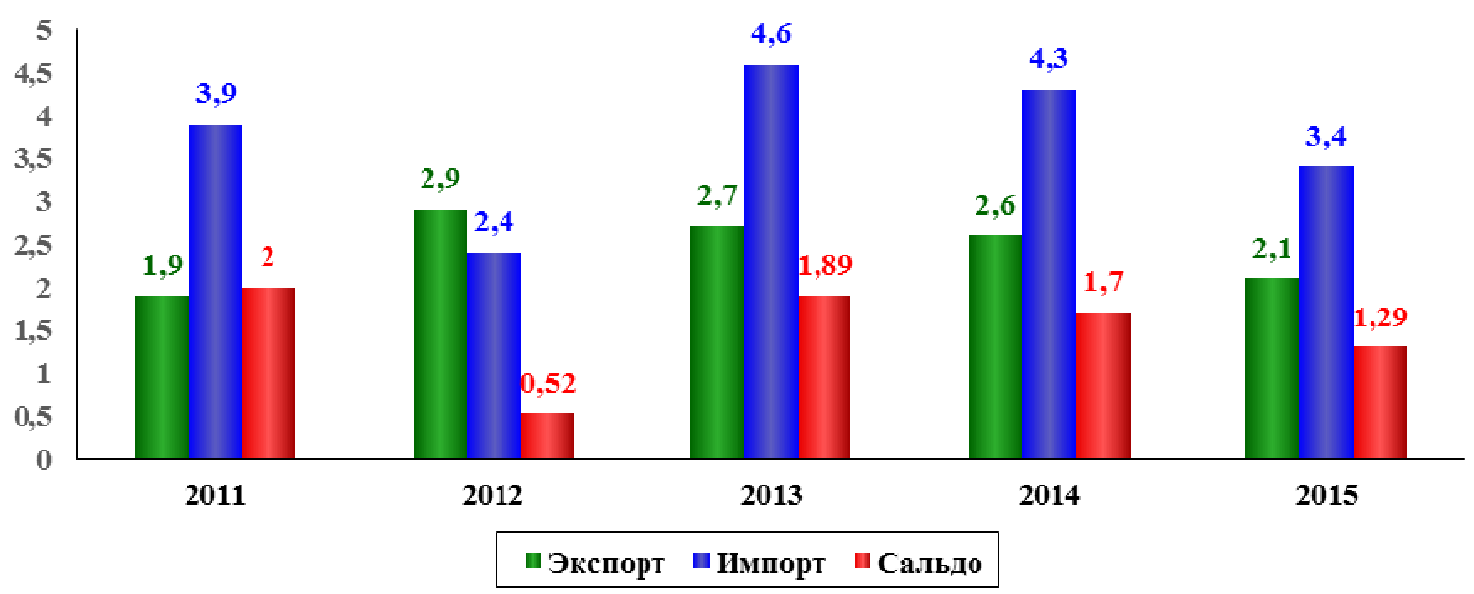

Экспорт-Export

Импорт-Import

Balance

The diagram 3 - Export, import and balance of production of AIC, billion US dollars

Export amounted to 24.9 thousand tons in the amount of 52.6 million US dollars. Import of fish and fish products amounted to 52.2 thousand tons to the amount of 61.5 million US dollars.

This system consists of several components that allow you to trace the chain of origin of products from the farm to the consumer's table. Thus, in order to increase consumers' confidence in domestic products, it is necessary to introduce world-class information systems for the registration of animals, traceability of the origin of livestock products that meet the requirements of importing countries of meat.

Table 2 - Institutes of state support of agroindustrial complex

\begin{tabular}{|l|l|l|}
\hline № & \multicolumn{1}{|c|}{$\begin{array}{c}\text { Groups of companies JSC NMH } \\
\text { "KazAgro" }\end{array}$} & \multicolumn{1}{c|}{ Mission } \\
\hline 1 & Food Contract Corporation & management of state grain resources on behalf of the state \\
\hline 2 & $\begin{array}{l}\text { Fund for Financial Support of } \\
\text { Agriculture }\end{array}$ & $\begin{array}{l}\text { microcrediting of the rural population and SSTP, lending to microcredit } \\
\text { organizations }\end{array}$ \\
\hline 3 & KazAgroFinance & $\begin{array}{l}\text { ensuring access of agricultural producers to financial resources, as well as to } \\
\text { agricultural machinery and technological equipment on a leasing basis }\end{array}$ \\
\hline 4 & Agrarian Credit Corporation & $\begin{array}{l}\text { development of an affordable credit system for the subjects of the agro-industrial } \\
\text { complex of the Republic of Kazakhstan }\end{array}$ \\
\hline 5 & KazAgroMarketing & $\begin{array}{l}\text { providing accessible information and marketing and consulting services to } \\
\text { agribusiness entities }\end{array}$ \\
\cline { 2 - 3 } 6 & KazAgroGarant & $\begin{array}{l}\text { stimulation of attracting investments in the agrarian sector by developing a } \\
\text { system for guaranteeing the fulfillment of obligations of the subjects of the AIC }\end{array}$ \\
\hline 7 & KazAgrounim & $\begin{array}{l}\text { ensuring food security and development of the export potential of the livestock } \\
\text { sector by supporting the production and promotion of livestock for export } \\
\text { products by agro-business entities }\end{array}$ \\
\hline
\end{tabular}

Subsidizing is used as a key instrument to support agricultural production and stimulate exports. The volume of subsidies to the industry in 2016 amounted to: plant growing - 43.4 billion tenge, livestock 41.6 billion tenge. By 2020, it is planned to increase the volume of state support to agriculture by subsidizing the subjects of the agro-industrial complex by 4.5 times [5].

The discussion of the results. Based on the analysis of Kazakhstan's geographical location, agricultural market capacities, transport accessibility, it can be concluded that the potential markets for sales remain the countries of the EEA, the CIS, China, Iran, Afghanistan and the UAE.

Leading in terms of exported products based on the results of 2015 are: - crop production - wheat, barley, corn, oilseeds; - livestock products - beef, pork, lamb, poultry. 
In general, in the structure of imports of such countries as Russia, Uzbekistan, Kyrgyzstan and Tajikistan, products from Kazakhstan account for more than $86 \%$ for certain types of crop products. Thus, in 2015 , the share of wheat from Kazakhstan totaled $86.6 \%$ of the total volume of the imported wheat rancid in Russia. In Uzbekistan's imports of wheat, flour and oilseeds, the share of products from Kazakhstan is $100 \%, 99.2 \%$ and $98.7 \%$, respectively.

According to livestock products, taking into account the domestic supply of domestic production, export potential has beef, pork and lamb. The largest volumes of imports of these products are observed in countries such as China, Russia, Iran and the United Arab Emirates.

The indicator of regional labor productivity of agricultural production is determined by the ratio of the value of agricultural production in the region for the year and the number of people employed in the region's agriculture (million tons / person). Agricultural products represent the sum of crop production and livestock production of all agricultural producers, including the population's economy, peasant (farm) farms and agricultural enterprises, in value evaluation at actually effective prices. The summarizing indicator of the regional competitiveness of agricultural production is the ratio of the profitability of production in agriculture to the productivity of labor employed in agricultural production:

$$
\mathrm{I}=\mathrm{P} / \mathrm{P}(1)
$$

Where

I - generalizing indicator of regional competitiveness of agricultural production

$\mathrm{P}$ - profitability of production in agriculture

$\mathrm{P}$ - productivity of labor employed in agricultural production [5].

Table 3. Calculation of the generalized indicator of the competitiveness of agricultural production

\begin{tabular}{|c|c|c|c|c|c|}
\hline Regions & $\begin{array}{c}\text { number of people } \\
\text { employed in } \\
\text { agriculture, } \\
\text { persons }\end{array}$ & $\begin{array}{l}\text { gross output of } \\
\text { agricultural } \\
\text { production mln. }\end{array}$ & $\begin{array}{c}\text { labor } \\
\text { productivity in } \\
\text { agriculture, } \\
\text { mln.tn / person. }\end{array}$ & $\begin{array}{l}\text { profitability } \\
\text { production } \%\end{array}$ & $\begin{array}{c}\text { generalizing } \\
\text { competitiveness } \\
\text { indicator }\end{array}$ \\
\hline Kazakhstan & 2125700 & 1999046,60 & 0,9 & 24,8 & 0,27 \\
\hline Akmola & 164200 & 148822,90 & 0,9 & 25,4 & 0,28 \\
\hline Aktobe & 72600 & 113468,00 & 1,6 & $-0,8$ & $-0,01$ \\
\hline Almaty & 428200 & 342543,20 & 0,8 & 22,7 & 0,28 \\
\hline Atyrau & 13300 & 40376,10 & 3 & 15,3 & 0,05 \\
\hline Western Kazakhstan & 90800 & 73418,90 & 0,8 & 4,1 & 0,05 \\
\hline Jambyl & 110200 & 94393,80 & 0,9 & 19,3 & 0,23 \\
\hline Karagandy & 88300 & 114056,70 & 1,3 & 20,6 & 0,16 \\
\hline Kostanay & 197300 & 184938,90 & 0,9 & 23,7 & 0,25 \\
\hline Kyzylorda & 34100 & 48505,20 & 1,4 & 8,5 & 0,06 \\
\hline Mangystau & 1500 & 7822,50 & 5,2 & 30,9 & 0,05 \\
\hline $\begin{array}{l}\text { Southern } \\
\text { Kazakhstan }\end{array}$ & 468400 & 259203,70 & 0,6 & 16,3 & 0,29 \\
\hline Pavlodar & 93400 & 79643,40 & 0,9 & 27,2 & 0,32 \\
\hline NorthernKazakhstan & 175400 & 252501,90 & 1,4 & 34,4 & 0,24 \\
\hline Eastern Kazakhstan & 188000 & 237221,80 & 1,3 & 45,8 & 0,36 \\
\hline
\end{tabular}

In essence, these indicators are a relative value of intensity, which shows how much tenge of profit is an average of one tenge of produced agricultural output (output). As a result of data processing, groups of regions were identified that characterize the features of the territorial formation of agricultural labor 
productivity indicators and the profitability of production, and the possibility of diversifying exports of the agroindustrial complex was identified by involving 10 regions of Kazakhstan in foreign economic activity.

The most competitive regions (East Kazakhstan, Akmola, Pavlodar, South Kazakhstan, Kostanay, Almaty oblasts) have a generalizing indicator of competitiveness at the level of 0.25 or more. The western regions of the country are the least competitive.

Table 4 - Classification of the regions of Kazakhstan by the level of competitiveness of agricultural production

\begin{tabular}{|l|l|l|}
\hline \multicolumn{1}{|c|}{ Competitiveness level } & \multicolumn{1}{|c|}{ Regions } & \multicolumn{1}{|c|}{ Average } \\
\hline Competitive (0.25 or more) & $\begin{array}{l}\text { East-Kazakhstan, Akmola, Pavlodar, South-Kazakhstan, } \\
\text { Kostanay, Almaty regions (6) }\end{array}$ & 0,25 \\
\hline $\begin{array}{l}\text { Having the potential of competitiveness } \\
(0.05-0.25)\end{array}$ & $\begin{array}{l}\text { Karaganda, Zhambyl, North-Kazakhstan, Kyzylorda } \\
\text { regions (4) }\end{array}$ & 0,18 \\
\hline $\begin{array}{l}\text { Lestobe, Atyrau, Western Kazakhstan, Mangystau } \\
\text { regions (4) }\end{array}$ & 0,04 \\
\hline $\begin{array}{l}\text { Note - Note - Author's calculations using data from the Ministry of National Economy of the Republic of Kazakhstan } \\
\text { Committee on Statistics }\end{array}$ \\
\hline
\end{tabular}

It should be emphasized that these indicators of competitiveness are generalizing, because the export potential in the agrarian sector of a particular region depends on a number of objective factors. So, in Kazakhstan there are differences between the natural and climatic conditions of the regions, the level of infrastructure development, the material and technical equipment of farms, which leads to a different cost of production of agricultural products at the level of the republic, at the level of individual regions. Ignoring such differences inevitably leads to the support of non-competitive industries. Therefore, specific specialization of regions is needed [6].

At the same time, the strategy of increasing competitiveness should be primarily focused on the development of the quality of life of the rural population. This is the only way to ensure a comprehensive approach to achieving the competitive advantages of the agricultural sector of the economy.

The directions of increasing the competitiveness of the agro-industrial complex should be expressed in three aspects:

- creation of a sustainable system of expanded reproduction of high-quality agro-food products;

- the maximum possible reduction of the gap in the social and economic development of urban and rural areas;

- the formation of a regional food security system that is resistant to internal and external threats and impacts (Figure 1).

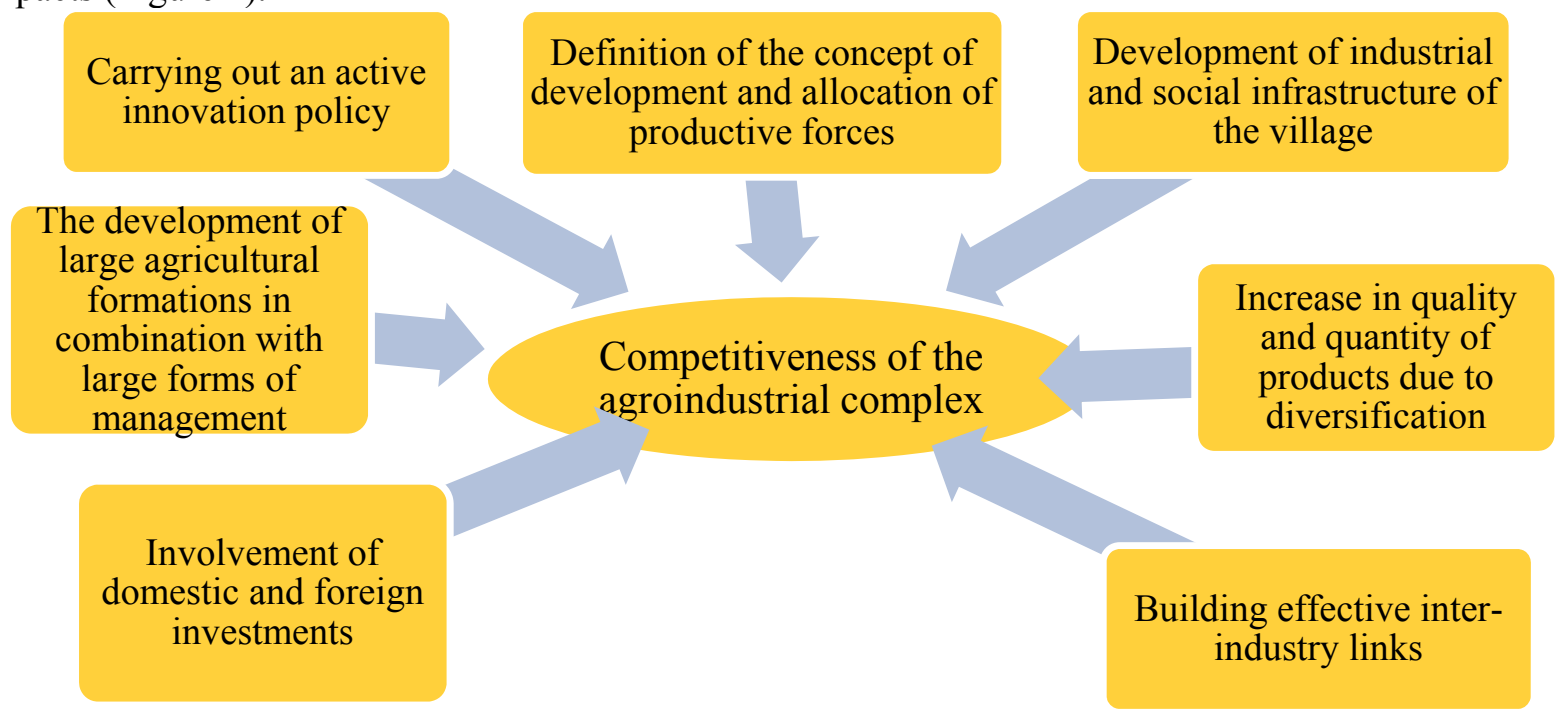

Note - Author's suggestions

Figure 1 - The basic directions of increase of competitiveness 
For realization of the indicated directions it is proposed:

- create the necessary conditions aimed at breaking the trend of outflow of the educated and young people from rural areas, as well as improve the level of rural education;

- to increase household incomes and self-sufficiency of rural residents;

- to promote innovative development of agriculture, mechanization and intellectualization of labor, and also to ensure transition to resource-saving technologies;

- to regulate land relations and expand access to factors of production;

- Develop the social infrastructure of the village, focusing on the degree of development of urban infrastructure;

- improve housing conditions in rural areas, by building modern and affordable housing;

- promote the use of marketing and information technology in agriculture;

- To significantly reduce the tax burden on all categories of agricultural producers, including, by way of complete exemption from taxation during the first five years of the operation of new entities of agrarian business;

- to form and promote the promotion of regional brands in Kazakhstan and foreign food markets;

- to reform unprofitable agricultural organizations, to develop small forms of management and cooperation [7].

At the same time, none of these areas of development can be implemented without adequate state support. Therefore, effective state support is a prerequisite for both improving product competitiveness and export capacity. At the same time, if the regional level of state support for exports is formed in some way, the local level in matters of involvement in the system of support and stimulation of exports is left without attention. The local level of organization and support for the export of agro-industrial complex is today the most important, since it allows attracting the largest number of participants in foreign economic activity (farms, small and medium-sized businesses).

Conclusions. Thus, on the basis of the conducted research, the problems that are the reason for the low competitiveness of the agricultural sector were systematized. Therefore, the implementation of the export potential of the agricultural sector is seen in addressing the issues of increasing the competitiveness of the industry. First of all, there is a need for a clear specialization of the regions of the country in the production of a particular type of agricultural products, taking into account the natural, climatic, organizational, production, investment and other characteristics of the regions, which will make it possible to use factors of production more efficiently, reduce production costs and, consequently, increase competitiveness. In connection with this, it is also necessary to review the measures of state support for the regions taking into account their specialization. In connection with the concentration of agricultural production in the households of the population, it is necessary to strengthen the local level of support for producers and exporters of agricultural products through the creation of a Territorial Export Support Center. In order to increase the competitiveness of products, it is necessary to continue work on the introduction of international quality standards, the development of processing industries. Increasing the competitiveness of products will help to strengthen the country's position in the world market as a reliable supplier of agricultural products and thus, all prerequisites will be created for increasing the export potential of the country's agrarian sector [8].

Export policy will be based on targeted support for the promotion of products in potential sales markets. For this purpose, due to own funds, NUK "KazAgro" JSC, "NC" Food Corporation "JSC will act as an export center of the agro-industrial complex in close cooperation with JSC" KazExportGarant "and JSC" National Agency for Export and Investment of JSC "KAZNEX INVEST", and also diplomatic missions abroad. The Center will:

1) analysis of external markets and drawing up of road maps of promotion of production for perspective countries of sale;

2) forward purchase of products from SHPP and formation of large export batches;

3) creation of export sales channels for agricultural products in demand on the foreign market;

4) provision of insurance and guarantee of export contracts of SHTP;

5) promotion of umbrella brands, including "KZ ORGANIC FOOD";

6) advisory services on export of products, including contract maintenance.

Also, to increase the attractiveness of the agricultural sector to investors, the Government will take 
measures to improve the position of the Republic of Kazakhstan in the Global Competitiveness Index of the World Economic Forum in terms of the indicator "The aggravation of agrarian policy", as well as the inclusion of Kazakhstan in the World Bank's "Enabling the Business of Agriculture" "Development of agribusiness").

\section{REFERENCES}

[1] Message from the President of the Republic of Kazakhstan N.A. Nazarbayev to the people of Kazakhstan on January 10, 2018 "New opportunities for development in the conditions of the fourth industrial revolution".

[2] The State Program for the Development of the Agro-industrial Complex of the Republic of Kazakhstan for 2017-2021

[3] A. Kurishbaev. Only the strategic development of agrarian science will allow Kazakhstan to create its own "Food Valley" // Problems of Modern Economy. - Almaty, - 2014. - №3. - 145 sec.

[4] The State Program for the Development of the Agro-industrial Complex of the Republic of Kazakhstan for 2017-2021.

[5] Ministry of National Economy of the Republic of Kazakhstan Committee on Statistics - www.stat.gov.kz

[6] Terms and stages of the implementation of the Program for the Development of the Agro-Industrial Complex in the Republic of Kazakhstan for 2013-2020 "Agro-business 2020"

[7] Ministry of Agriculture of the Republic of Kazakhstan http: - mcx.gov.kz/ru

[8] JSC National Holding Company KazAgro

\section{Г. Т. Султанова}

АО «Финансовая академия», Астана, Республика Казахстан

\section{ТЕНДЕНЦИИ И ПРИОРИТЕТЫ РАЗВИТИЯ ЭКСПОРТНОГО ПОТЕНЦИАЛА АГРАРНОГО СЕКТОРА}

Аннотация. Актуальность развития научных исследований определяется тем, что Агропромышленный комплекс является основной и наиболее перспективной отраслью экономики Казахстана.

Ключевые слова: тенденции, агропромышленный комплекс, продукты питания, государственная поддержка, валовая продукция сельского хозяйства, механизм развития сельского хозяйства, интеллектуализация труда, ресурсосберегающие технологии.

\section{Г. Т. Султанова}

«Қаржы академиясы» АҚ, Астана қаласы, Қазақстан Республикасы

\section{АГРАРЛЫК СЕКТОРДЫН ЭКСПОРТТЫК ӘЛЕУЕТІН ДАМЫТУҒА БАҒЫТТАЛҒАН ҮРДІСТЕР МЕН БАСЫМДЫҚТАР}

Аннотация. Ғылыми зерттеулерді дамытудың өзектілігі Агроөнеркәсіптік кешен Қазақстан экономикасының басты және перспективалы секторы болып табылады.

Түйін сөздер: үрдістер, агроөнеркәсіптік кешен, азық-түлік өнімдері, мемлекеттік қолдау, ауыл шаруашылығының жалпы өнімі, ауыл шаруашылығын дамыту механизмі, еңбек интеллектуациясы, ресурс үнемдейтін технологиялар.

Information about authors:

Sultanova Guzel Tahirovna - PhD doctoral student of the 2-nd year, guzel1010@mail.ru 


\section{МАЗМҰНЫ}

Алтыбаева С.М., Савындыков Е.С. Көркем мәтін құрылымындағы мифопоэтикалық модельдеу және мәдени код...... 5 Сембиева Л.М., Мажитов Д.М., Карпиикая М.Е., Хамитова Д.М. Экономиканы жаңғырту жағдайындағы ЕАЭО елдерінің монетарлық жүесінін өзгеруі .....

Құлсариева А.Т., Султанова М.Э., Шайгозова Ж.Н. Фольклор және сәйкестілік: Қазақстанның қазіргі заманғы

мәдениетіндегі тарих, жады және аңыз шығармашылығы ........................................................................................... 19

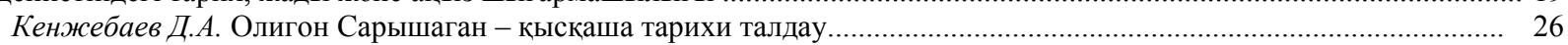

АбдулинаГ.А., БазарбаевА.Г. Ұйымдардағы адам ресурстарын басқарудың заманауи тұжырымдамалары................ 33

Авыбаев А.Н., Адибаева А.К. Геноцид туралы БҰҰ Конвенциясының қатысушы мемлекеттердің қылмыстық

заңнамаларындағы имплементациялық тетіктері: жалпы салыстырмалы талдау............................................................ 39

Ахметжанов Б., Тәжібекова К.Б., Шаметова А.А. Қазақстан көлік өнеркәсіптің дамуын талдау............................. 44

Аюпова 3.К., Құсайынов Д.Ө. Тәуелсіздік жағдайындағы қазақстан республикасының конституциялық-құқықтық

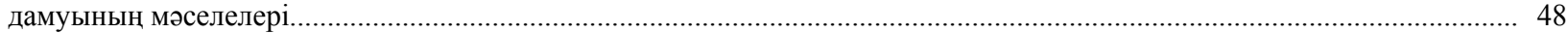

Нурпеисова А.А., Рей И.Ю., Бижанов Д.Т., Тлеужанова Д.А. Инновациялық өндірісді жасаудың процесін

бақылауының негізгі элементтері

Гиздатов Г.Г. Қазақстандық дискурсының құрылымы психолингвистиякалық зерттеу .

Ищанова Р.К. Мемлекеттік шығындарды басқару - мемлекеттің қаржылық тұрақтылығын қамтамасыз ету.............. 64

Мадышева А.М. Бикенова А.С., Елеусиз Л.Т. Білім саласындағы туристік қызметтер............................................. 68

Ескалиева А. Ж., Баймуханова М.Т., Ахмурзина Д.О. Әлеуметтік сала адам капиталының сапасын қолдаудың

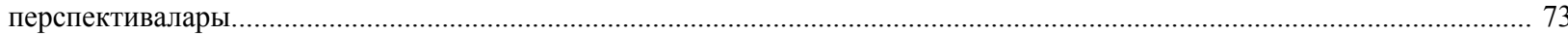

Мархаева Б.А., Козбахова Д.Л. Жауапкершілік орталық және трансферттік баға белгілеу............................................ 79

Сабирова Р.К., Утепкалиева К.М., Кабаков С.Б. Қазақстандағы ауыл шаруашылығы экономикасының

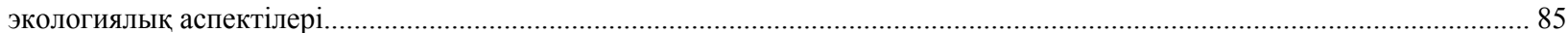

Тлесова Э., Хойч А., Кураш Н. Қазақстан республикасының ғылыми инновациялық потенциясы және оның

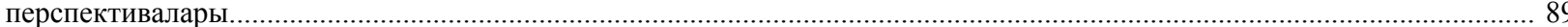

Хамитхан Н. Қазақстандағы банктік қызметтердің сапасын жақсарту жағдайында банкаралык басекелестік............ 95

Шалдарбеков Қ.Б., Муханова Г.С., Нурмухамбетова 3.С. Аймақтарды дамыту бағдарламаларын жүзеге асырудағы жобалық басқаруды қолданудың шетелдік тәжірибесі

КаратаеваА.М., Бердиярова Ж.С. Мемлекеттік қызметшінің әдептік мәдениеті және құқықтық мәдениеті

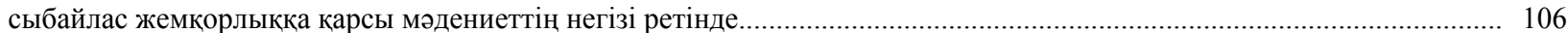

Алдабергенова А.А. Абсурд әдебиетін аударудың лингвомәдени аспектілері ................................................... 113

Стукач В. Ф., Байдалинова А. С., Сандыбаева Б. А. Қазақстанның қаржылық қауіпсіздігі......................................... 119

Баймаханова Д.М., Оспанова Д.А. Конституциялық-құқықтық сана - конституционализмнің маңызды

компоненті ретінде және оның адам құқықтары мәселелерін шешудегі рөлі................................................................. 126

Имангожина 3.А. Сланцевая революция: глобальный тренд на мировом энергетическом рынке............................. 137

Ракаева А.Н., Жуматаева Б.А., Успамбаева М.К., Доскалиева Б.Б. Экологиялық есеп қазақстандағы кәсіпорын экономикасының даму кезеңі ретінде

Нуржанова Г.И. Экономиканың аграрлық секторындағы еңбек әлеуетіне демографиялық фактордың әсері............ 147

Оспанова Д.А., Баймаханова Д.М. Қазақстан Республикасының кибер кеңістігін дамыту жағдайында мемлекеттік қызметтерді цифрландыруда әкімшілік-құқықтық қамтамасыз ету ................................................................................... 152

Pblсnекова М.О., Тлесова Э.Б., Хаитбаева Ф.К. Қазақстандағы тұрғын үй-коммуналдық шаруашылық қызметін

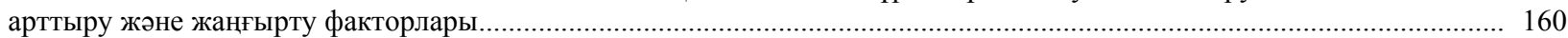

Султанова Г. Т. Аграрлық сектордың экспорттық әлеуетін дамытуға бағытталған үрдістер мен басымдықтар........ 166 


\section{СОДЕРЖАНИЕ}

Алтыбаева С.М., Сагындыков Е.С. Культурный код и мифопоэтическое моделирование в структуре художественного текста.

Сембиева Л.М., Мажитов Д.М., Карпиикая М.Е., Хамитова Д.М. Трансформация монетарной системы стран

ЕАЭС в условиях модернизации экономики.............................................................................................................

Кулсариева А.T., Султанова М.Э., Шайгозова Ж.Н. Фольклор и идентичность: история, память и мифотворчество

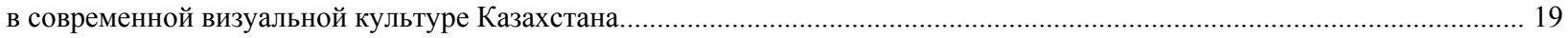

Кенжебаев Д.А. Полигон Сарышаган - краткий исторический анализ................................................................ 26

Абдулина Г.А., БазарбаевА.Г. Современные концепции управления человеческми ресурсами в организациях........... 33

Агыбаев А.Н., Адибаева А.К. Имплементационные механизмы Конвенции ООН о геноциде в уголовных

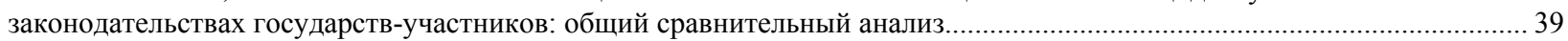

Ахметжанов Б., Тажибекова К.Б., Шаметова А.А. Анализ развития угольной промышленности Казахстана........... 44

Аюпова 3.К., Кусаинов Д.У.Проблемы конституционно-правового развития республики Казахстан в условиях

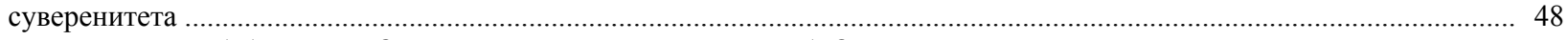

Нурпеисова А.А., Рей И.Ю., Бижанов Д.Т., Тлеужанова Д.А. Основные элементы управления процессом создания

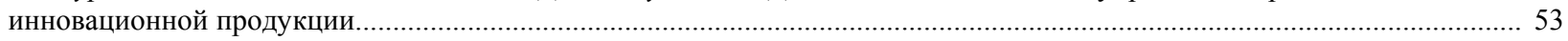

Гиздатов Г.Г. Психолингвистическое исследование концептов казахстанского дискурса...................................... 57

Ищанова Р.К. Управление государственными расходами - как обеспечение финансовой устойчивости государства. 64

Мадымева А.М. Бикенова А.С., Елеусиз Л.Т. Туристские услуги в сфере образования........................................... 68

Ескалиева А. Ж., Баймуханова М.Т., Ахмурзина Д.О. Перспективы усиления качества человеческого капитала

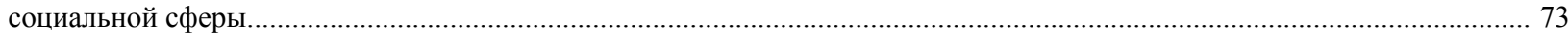

Мархаева Б.А., Козбахова Д.Л. Центр ответственности и трансфертное ценообразование..................................... 79

Сабирова Р.К., Утепкалиева К.М., Кабаков С.Б. Экологические аспекты экономики сельского хозяйства

в Казахстане........................................... 85

Тлесова Э., Хойч А., Кураш Н. Научно-инновационный потенциал республики Казкастан и его перспективы............ 89

Хамитхан Н. Межбанковская конкуренция в условиях повышения качества банковских услуг в Казахстане.............. 95

Шалдарбеков К.Б., Муханова Г.С., Нурмухамбетова 3.С. Зарубежный опыт применения проектного управления

при реализации программ развития регионов

Каратаева А.М., Бердиярова Ж.С. Этическая культура и правовая культура государственных служащих

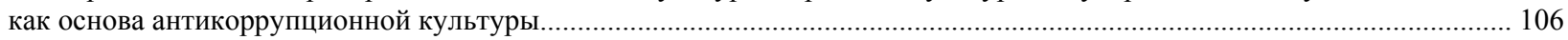

Алдабергенова А.А. Лингвокультурологические аспекты перевода литературы абсурда.......................................... 113

Стукач В. Ф., Байдалинова А. С., Сандыбаева Б. А. Казахстанская финансовая безопасность.................................... 119

Баймаханова Д.М., Оспанова Д.А. Конституционно-правовое сознание как важный компонент конституционализма

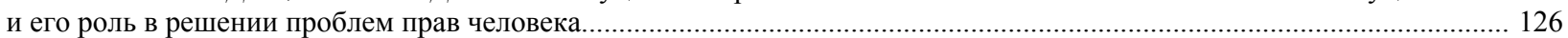

Имангожина 3.A. Сланцевая революция: глобальный тренд на мировом энергетическом рынке............................. 137

Ракаева А.Н., Жуматаева Б.А., Успамбаева М.К., Доскалиева Б.Б. Экологический учет как ступень развития

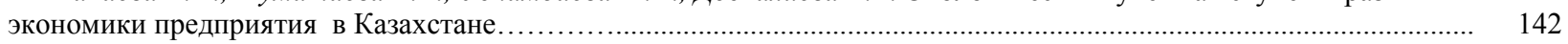

Нуржанова Г.И. Влияние демографического фактора на трудовой потенциал аграрного сектора экономики............ 147

Оспанова Д.А., Баймаханова Д.М. Административно-правовое обеспечение цифровизации государственных услуг

в условиях развития кибер пронстранства республики Казахстан..

Pыспекова М.О., Тлесова Э.Б., Хаитбаева Ф.К. Факторы инновационной модернизации и совершенствования

деятельности жилищно-коммунального хозяйства в Казахстане.

160

Султанова Г. Т. Тенденции и приоритеты развития экспортного потенциала аграрного сектора................................ 166 


\section{CONTENTS}

Altybayeva S.M., Sagyndykov E.S. Cultural code and myth poetic modeling in the structure of the artistic text..................... 5 Sembiyeva L.M., Mazhitov D.M., Karpitskaya M.E., Khamitova D.M. Transformation of the monetary system of the eurasian economic UNION countries in the conditions of modernization of the economy......

Kulsarieva A.T., Sultanova M.E., Shaigozova Zh.N. Folklore and identity: history, memory and myth-making in the modern

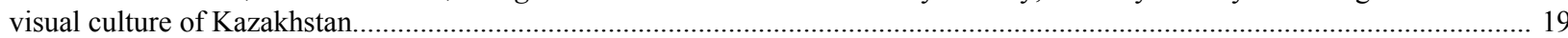

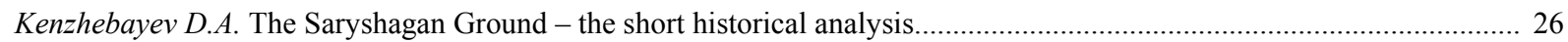

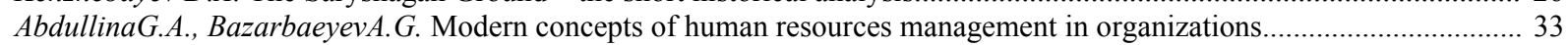

Agybayev A.N., Adibayeva A.K. Implementing mechanisms of the UN Convention on genocide in the criminal legislation

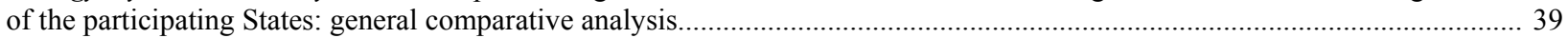

Akhmetzhanov B., Tazhibekova K.B, Shametova A.A. Analysis of development of the coal industry of Kazakhstan.............. 44 Ayupova Z.K., Kussainov D.U. Problems of constitutional and legal development of the republic of kazakhstan in the conditions of sovereignty......

Nurpeisova A.A., Rey I.Yu., Bizhanov D.T., Tleuzhanova D.A. Main elements of managing the process of creating innovation production.

Gizdatov G.G. Psycholinguistic study of the concepts of Kazakhstar

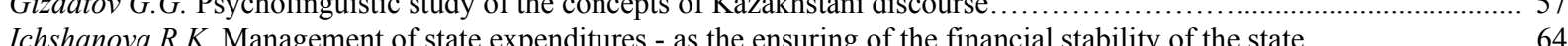

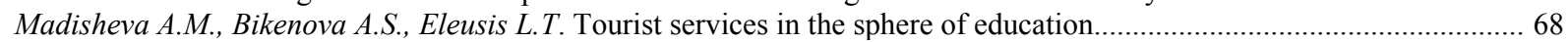

Eskalieva A. Zh., Baymukhanova M.T., Ahmurzina D.O. Perspectives of strengthening the quality of the human capital

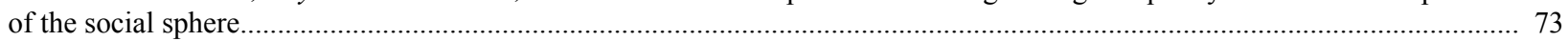

Markhayeva B.A., Kozbakhova D.L. A responsibility center and transfer pricing ................................................. 79

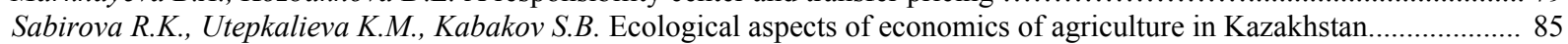

Tlessova E., Khoich A., Kurash N. Scientific innovation potential of the republic of Kazkahstan and its perspectives........ 89

Hamitkhan $N$. Interbank competition in conditions of improving the quality of banking services in Kazakhstan.................. 95

Shaldarbekov K., Mukhanova G., Nurmukhambetova Z. International practices in project management in implementing

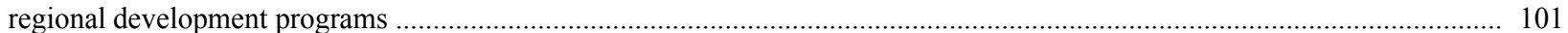

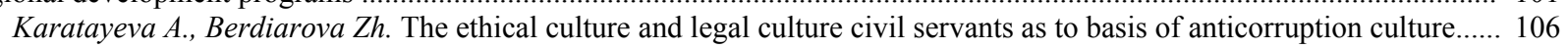

Aldabergenova A.A. Linguocultural aspects of translation of absurd literature.............................................................. 113

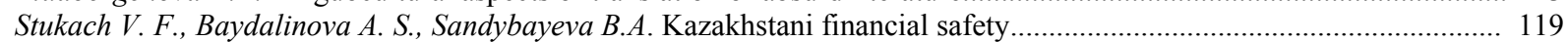

Baimakhanova D.M., Ospanova D.A. Constitutional and legal consciousness as an important component of constitutionalism

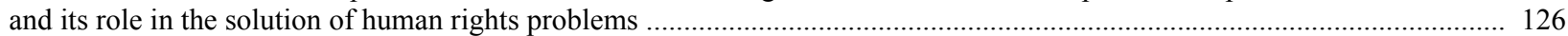

Imangozhina Z.A. Shale gas revolution: global trend in the world energy market..................................................... 137

Rakaeva A.N., Zhumataeva B.A., Uspanbayeva M.K., B.B.Doskalieva. Level of ecological report development in the economic of Kazakhstan's companies.

Nurzhanova G.I. Impact of demographic factors on labor potential of economy's agricultural sector

Ospanova D.A., Baimakhanova D.M. Administrative and legal support of digitalization of public services in the context of the development of cyber space in the republic of Kazakhstan....

Ryspekova M.O., Tlessova E.B., Khaitbayeva F. Factors of innovative modernization and improvement of activity

of housing and communal services in Kazakhstan.

Sultanova G. T. Trends and priorities for the development of export potential of the agrarian sector. 


\title{
PUBLICATION ETHICS AND PUBLICATION MALPRACTICE IN THE JOURNALS OF THE NATIONAL ACADEMY OF SCIENCES OF THE REPUBLIC OF KAZAKHSTAN
}

For information on Ethics in publishing and Ethical guidelines for journal publication see http://www.elsevier.com/publishingethics and http://www.elsevier.com/journal-authors/ethics.

Submission of an article to the National Academy of Sciences of the Republic of Kazakhstan implies that the work described has not been published previously (except in the form of an abstract or as part of a published lecture or academic thesis or as an electronic preprint, see http://www.elsevier.com/postingpolicy), that it is not under consideration for publication elsewhere, that its publication is approved by all authors and tacitly or explicitly by the responsible authorities where the work was carried out, and that, if accepted, it will not be published elsewhere in the same form, in English or in any other language, including electronically without the written consent of the copyrightholder. In particular, translations into English of papers already published in another language are not accepted.

No other forms of scientific misconduct are allowed, such as plagiarism, falsification, fraudulent data, incorrect interpretation of other works, incorrect citations, etc. The National Academy of Sciences of the Republic of Kazakhstan follows the Code of Conduct of the Committee on Publication Ethics (COPE), and follows the COPE Flowcharts for Resolving Cases of Suspected Misconduct (http://publicationethics.org/files/u2/New Code.pdf). To verify originality, your article may be checked by the originality detection service Cross Check http://www.elsevier.com/editors/plagdetect.

The authors are obliged to participate in peer review process and be ready to provide corrections, clarifications, retractions and apologies when needed. All authors of a paper should have significantly contributed to the research.

The reviewers should provide objective judgments and should point out relevant published works which are not yet cited. Reviewed articles should be treated confidentially. The reviewers will be chosen in such a way that there is no conflict of interests with respect to the research, the authors and/or the research funders.

The editors have complete responsibility and authority to reject or accept a paper, and they will only accept a paper when reasonably certain. They will preserve anonymity of reviewers and promote publication of corrections, clarifications, retractions and apologies when needed. The acceptance of a paper automatically implies the copyright transfer to the National Academy of sciences of the Republic of Kazakhstan.

The Editorial Board of the National Academy of sciences of the Republic of Kazakhstan will monitor and safeguard publishing ethics.

Правила оформления статьи для публикации в журнале смотреть на сайте:

$$
\begin{gathered}
\text { www:nauka-nanrk.kz } \\
\text { social-human.kz }
\end{gathered}
$$

\author{
Редакторы М.С. Ахметова, Т.А. Апендиев, Д.С. Аленов \\ Верстка на компьютере А.М. Кульгинбаевой \\ Подписано в печать 10.10.2018 \\ Формат 60x881/8. Бумага офсетная. Печать - ризограф. \\ 11,6 п.л. Тираж 500. Заказ 5.
}

